\title{
Strategies and Tools for Effective Awqaf Asset Management
}

\author{
Hidayatul Ihsan ${ }^{1}$, Eliyanora ${ }^{2}$, Nurul Fauzi ${ }^{3}$, Gustina ${ }^{4}$, Abdelgani Echchabi ${ }^{5}$ \\ \{hidayatul@pnp.ac.id'1 ,norabuan93@gmail.com²,nurfa2006@yahoo.co.id ${ }^{3}$, gustina@pnp.ac.id ${ }^{4}$, \\ aechchabi@hct.ac.ae ${ }^{5}$. \\ Accounting Department, Padang State Polytechnic, Indonesia ${ }^{1,2,3}$, Business Administration Department, \\ Padang State Polytechnic, Indonesia ${ }^{4}$, Higher Colleges of Technology Dubai, United Arab Emirate ${ }^{5}$
}

\begin{abstract}
Waqf is known to have played significant role over the years as an effective tool of poverty eradication through the provision of essential facilities and public goods for Muslim society. Unfortunately, in recent years, the vast potential of waqf has not been utilised optimally. The lack of required attention has subjected many waqf assets to abuse and neglect. Poor management and ineffective regulation among others issues greatly undermine the potential of waqf in many Muslims communities nowadays. The focus of this paper is to explore the strategies and tools to manage waqf assets effectively. In doing so, series of focus group discussions and interviews were conducted with mutawalli, waqf regulator and academicians. The findings of the study indicate that the role of effective regulation, improved waqf governance, appropriating financing instruments and continuous education is equally important as strategies in developing waqf assets. In addition, this study suggests some important mechanisms particularly accountability and risk management that are necessary for developing the right strategy for waqf administration.
\end{abstract}

Keywords: Waqf, regulation, governance, financing, accountability, risk management, education

\section{Introduction}

It is unquestionably true that waqf possesses huge potential to support socio-economic development. Throughout history, waqf is known to have played significant role as an effective tool of poverty eradication through the provision of essential facilities and public goods for Muslim society. No wonder, therefore, recent years have witnessed the expectation of waqf to overcome economic disparities and to alleviate poverty as well as to be able to lift up national economic growth.

Unfortunately, the vast potential of waqf has not been utilised optimally. In Indonesia, for example, out of 4.9 billion meter square of waqf lands, more than $60 \%$ were still utilised for the purpose of mosques and musalla. It does not mean that using waqf for religious purposes is not good. But, waqf could be more beneficial than that. In fact, waqf possesses wider philanthropic potentiality for poverty alleviation and social welfare [1]. 
Hence, managing waqf to be economically productive could be one of the strategies to reach the greatest potential of waqf.

Despite the growing expectation for waqf, many waqf institutions today fail to take it seriously. It is true that in some countries there have been many cases of good practices of waqf. However, it should be admitted that the cases of abuse and neglect of waqf assets are still there [2],[3]. Ironically, Rashid indicates that in some part of Muslim countries, the perception about those persons who manage waqf assets is one associated with dishonesty, corruption and mismanagement [4]. Poor management and ineffective regulation are among others issues greatly undermine the potential of waqf in many Muslims communities nowadays. This paper, therefore, aims at exploring the strategies and tools to manage waqf assets effectively.

\section{The Current Portraits of Waqf Development}

There have been systematic efforts made to accelerate the agenda of waqf revitalisation in the last few years. The Islamic Development Bank (IDB) and Islamic Research and Training Institute (IRTI) have been on the frontline in promoting waqf revitalization agenda in the last two decades. Many international waqf conferences, seminars dan workshops were held in many countries. In addition to this, waqf becomes a favourite topic among master and Ph.D students, in the area of Islamic economics. It indicates growing interest in waqf as one of the tools for community development.

It is heartening to note that in recent years, waqf development around the world is heading towards betterment. The existing literatures show that there are quite a number of success stories of waqf around the world. The efficient waqf administration by Majlis Ugama Islam Singapore (MUIS) [5], the innovative waqf management by Jcorp in Malaysia [6] and creative mutawalli such as Dompet Dhuafa in Indonesia [7] have given new hope towards revival of this historic institution. An amazing story of Zam Zam tower also inspires other Muslim countries to follow the same step.

However, it should be admitted that not all waqf institutions have obtained the same achievement. There are still large number of awqaf assets underdeveloped, under-utilized or even some are expropriated and lost [8]. There are many problems that hinder waqf in improving the quality of life of Muslim societies [1]. Subsequently, ineffective waqf management could slow down the revival of waqf. Indeed, to actualize the agenda of waqf revitalization, many requirements should be fulfilled.

Most of previous studies on waqf development were conducted in a case based [5], [6], [7]. The fact that waqf development requires a systematic effort has called for a more comprehensive study to scrutinize factors that can boost the management of waqf properties effectively. There are, actually few discussions on the determinants of waqf success [1], [8], but still limited in conceptual discourse. An empirical investigation on this topic is needed, hence gives a new room for a new study to conduct.

\section{Research Methods}

This research is an exploratory study. In particular, this study employed multi-sited fieldwork approach in gauging the opinion of various parties related to the strategies and tools to develop waqf properties. Therefore, many persons have been selected as respondents. The first 
group of respondent is mutawallis from three different waqf institutions. The second group is waqf regulator and the last group is academicians. The rationale behind the selection of the group is due to the fact that these parties are believed to be involved in waqf issue intensively.

In collecting data, there were two methods used, focus group discussions and personal interviews. There were four focus groups discussion which involved academicians and waqf regulator. Meanwhile, personal interviews were mostly conducted with the mutawalli. Moreover, in analysing the findings, a thematic network was employed. Using a thematic network enables the researcher to summarize key features of large data; highlighting the similarities and differences in the data [9].

\section{Findings and Discussion}

\subsection{Some Strategies to Develop Waqf Properties}

There are six themes emerged from the findings which are believed can foster the effective management of waqf properties. They are provision of law, financing, good governance, risk management, mechanisms of accountability and continuous and massive education. Each of these themes will we elaborated further in the following section.

\subsubsection{Provision of Law}

In Indonesia, although waqf already hold its legal standing, some amendments are still needed. For instance, there is a demand from the waqf regulator to strengthen the role of the Indonesian Waqf Board (BWI) as the sole waqf regulator in Indonesia. This fact was indicated from the interview with one of the BWI commissioners:

From the institutional perspective, the status of BWI as the waqf regulator has not been implemented effectively. We [BWI] are still depending on the government, that is, the ministry of religious affairs. BWI still has limited authority as the regulator. Hence, there has been an idea to amend the existing waqf law, thus enable BWI to have more power.

Other than the abovementioned fact, the harmonization of waqf law and other regulation is also necessary as it some circumstance, it is found that other regulation is not in line with waqf. This is somehow not compatible with the spirit to develop waqf property. One of academicians stated that,

For instance, once we had a plan to build students' dormitory. And we wanted to build this dormitory on waqf land. But at the end, it could not be implemented because if the dormitory will be funded by the government, the ownership of the dormitory will go to the government. So, we can't build the dormitory based on waqf, unless the status of asset is switched to the government asset. This is a problem. The regulation is not comprehensive [in regulating waqf]

In the global context, the important of provision of waqf law has also become an issue. One of the main obstacles for the development and growth of waqf institution is lack of 
proper legal framework. The absent of sufficient law provision for waqf would cause many problems. Many cases of waqf disputes are due to the law do not protect the assets, waqifs, mutawalli and beneficiaries adequately. As pointed out by Dafterdar, donors and financers are more likely to be comfortable to contribute to organisations whose operations have clear legal and regulatory environment [8].

Other than Indonesia, there are some countries actually already had their own waqf law such as India, Pakistan, and Malaysia (in the State level) [10]. Some other countries like Nigeria [11] Bosnia [12] and Thailand [13], do not have specific waqf law. Country like Bangladesh has Waqf ordinance, but it is considered no longer sufficient to regulate waqf [14]. It indicates that there are a lot of works to do to reform waqf legal framework.

Thus, in the international level, Dafterdar suggest developing an international model of waqf law [8]. Countries can adopt this framework with variations. This idea can be considered due to the fact that there are still quite a number of Muslim countries do not have waqf legislation. Perhaps, Waqf Core Principles is a starting point as it addresses the issue of legal foundation.

\subsubsection{Financing}

There are many cases where the mutawalli face difficulties to find the mode of financing to develop waqf properties. One of the mutawallis said,

For the big mutawalli, financing waqf property is not an issue. They have many sources of funding. But for small mutawalli, we can't fulfil the waqif's wish without proper financing.

There are some various practices found in the field with regard to waqf financing. For example, Dompet Dhuafa in Indonesia uses zakat fund to finance waqf property. They took the portion for the poor in this regard. The weakness of using this mode is that, they use of waqf property later on will be limited to the poor. In fact, waqf is not necessarily for the poor and the needy. Public in general can also get benefit form waqf assets.

Another model is as practised by Daarut Tauhiid. Upon the contract, they seek for waqif's approval to deduct up to $5 \%$ from cash waqf donated. Hence, it is only $95 \%$ of total donation will be recognised as waqf. However, this mode is more applicable to cash waqf, while for fixed assets waqf it could be little bit complited, unless the waqifs are willing to give another donation as sadaqah.

Some modes of financing actually have been proposed by researchers such as mursad loan, hukr, mudharabah and musharakah [1][15]. Expecting the government to finance waqf assets is almost impossible. Hence, there should be appropriate mode of waqf financing [1]. He advised that financing modes could be either from local financial institutions, foreign Islamic banks or self financing schemes.

Overall, the appropriate model of financing could be different. It varies; depend on the scale of waqf and traditions in each region. However, Kahf identifies two viable modes of waqf financing, that is, creation of cash waqf fund and establishment of bank for temporary waqf deposits [15]. For the first alternative, the idea is that, a new waqf is established for financing the existing waqf properties. This model actually had been practised widely in the past in Aceh, Indonesia. An asset called wakeuh was set up to support the main waqf assets. The second idea is that, a bank of temporary waqf deposit is created to utilise for financing the development of waqf. 


\subsubsection{Good Governance}

In the business entity, the idea of corporate governance is to ensure that there is no asymmetry information between the principal and agent. The following opinion of accounting academician emphasizes the important of good governance in waqf.

If we talk about good governance in waqf, of course it is very important. Because, it is related to the trustworthiness. It is related to trust on the mutawalli who are entrusted to manage waqf. Its conception might not be much different with the governance in general. It might encompass transparency, accountability, responsibility, integrity and fairness.

Apparently, agency theory suggests that the provider of fund to corporation need assurance on getting return on their investment. Meanwhile, the managers as the agent have motivation to work to get their incentive. However, this might not be applicable to waqf, as waqifs do not donate their assets to get financial return. Similarly, mutawallis manage waqf not in bonus motive. Nevertheless, good governance of waqf is crucial, because it goes beyond economic motives. The trust (amanah) is the reason behind waqf good governance. While mutawalli is working to maintain the trust from the public, the waqif need to ensure the intended purposes of creating waqf is achieved.

Some aspects waqf good governance should be in place. Risk management, accountability are among the requirements to ensure the best practice. In addition to this, the supervision should also prioritise. There should be a mechanism of control on the mutawalli. Supervision on the shariah compliance matter and other managerial aspects are needed in this regard. The issue of waqf good governance is specifically addressed in the Waqf Core Principles no 13.

\subsubsection{Risk Management}

Managing waqf assets bears the risks. Be the waqf is for social purposes, or it is addressed to generate profit, the risks are there. Risk is an adverse event which occurs due to an event that deviates from the expected one. Indeed, the Waqf core principles (WCP) specifically address the risk management issue in WCP no 14 to 24 . The most relevant risks identified in WCP are counterparty risk, country and transfer risks, market risk, reputation and waqf asset loss riks, revenue/profit sharing risk and disbursement risk. The respective waqf supervisor should therefore be able to identify, measure, monitor, report, control or control these risks.

Among other things, the reputation risk is essential to mitigate by the waqf supervisor and mutawalli. This is due to the fact that managing waqf is closely related to amanah. Once the reputation of mutawallis is harmed, they will lose public trust.

One of BWI commissioners who also involved in the preparation of WCP asserted that risk management is closely related to risk management.

The main issue in the WCP is related to the risk management. It resembles bank's management where the prudential is needed. So it [waqf] can be well managed. As we know, waqf may not be diminished. It should be managed productively. That's why we referred to the Basel principles in preparing the WCP 


\subsubsection{Mechanisms of Accountability}

In order to show accountability to wide range of stakeholder, mutawalli needs mechanisms of accountability. Either the mutawalli or waqf regulator agreed that accountability is of the essence in managing waqf. Not only important, accountability is also perceived as being compulsory.

It is arguably true that accountability had underpinned the success story of waqf in the past, while its decline was attributed to the degradation of the mutawalli's accountability [16]. Accountability is indeed not only limited to financial statement [17]. Ihsan et al in their study used mechanisms of accountability proposed by Ebrahim which can be applied for waqf too [7][18]. Those mechanisms encompass disclosure statements and reports, performance assessment and evaluation, participation, self-regulation and social auditing.

Disclosure statements and reports do not necessarily appear in the form of financial reporting per se. The financial statement is only one of the examples of disclosure statements. Other disclosure statements can be in the form of information about the organisational structure and programme. Disclosure statements and reports are the most widely used accountability tools, which are required by state law in many countries.

Performance assessment is another widely used mechanism of accountability. Performance assessment cannot be simply equated with evaluation. Performance assessment is actually part of evaluation. To be precise, performance assessment focuses on projects or programmes while evaluation overlooks the organisations as a whole. Moreover, performance assessment should encompass financial and non-financial measures. The purpose of evaluation is not only to evaluate performance towards the projects but also to facilitate the organisational learning process. Therefore, the evaluation should emphasize long-term organisational achievement rather than short-term quantitative targets

Participation is different from the two previous mechanisms because it is classified as a process instead of a tool. Participation can be differentiated into four levels. The first level of participation refers to any efforts made by the organisation to ensure that information about a planned project is available to the public. The second level of participation is through the involvement of the public in the project implementation, especially in the form of labour contribution of fund donations. The third level of participation includes the ability of the citizens to bargain over an organisation's decisions. At the fourth level, people have their own initiatives independently over an organisation's projects.

Self-regulation refers to efforts made by waqf institutions to develop standards or codes of behavior and performance. Self-regulation is important not only because it can improve the public image of the organisation but it also enhances the performance. Indeed, self-regulation improves accountability to the funders, communities and to the organisation itself.

Social auditing is defined as a "regular, externally verified process to understand, measure, report on and improve upon an organisation's social performance through stakeholder dialogue" [19]. Although social auditing seems likely to overlap with participation, Ebrahim argues that it is an integrated element of all the previous mechanisms discussed above .

It can be said that to achieve wider range of accountability, waqf institutions should use various mechanisms of accountability. Relying on financial statement to discharge accountability is not enough. Financial statement has weakness in that it can only be understood by those who have accounting knowledge. Hence, other mechanisms are needed to reach various level of stakeholders. 


\subsubsection{Continuous and Massive Education}

There is misconception on waqf among Muslim society. Waqf is perceived as associated with religious purposes such as mosques and Islamic boarding schools [20]. Managing waqf like business entity and generate profits is presumed to be alien for some people. This phenomenon was admitted by the one of mutawalli. He said,

We regularly delivered waqf talk in radio. And surprisingly we received many positive responses from the audience. This is interesting and we have realized that waqf needs public education as well. Public needs to know that nowadays there are many types of waqf, including productive waqf.

Therefore, in order to bring the agenda of waqf revitalisation in place, massive and continues education should be conducted. Not only to the stakeholders, education should also be addressed to Mutawallis. The waqf paradigm should be change from the traditional ones. Waqf management in the future should be professional, accountable and transparent.

\section{Concluding Remarks}

This study explores the strategies and tools to manage waqf assets effectively. Having discussed the strategies for effective awqaf assets management from various perspectives, this paper concludes with the following framework.

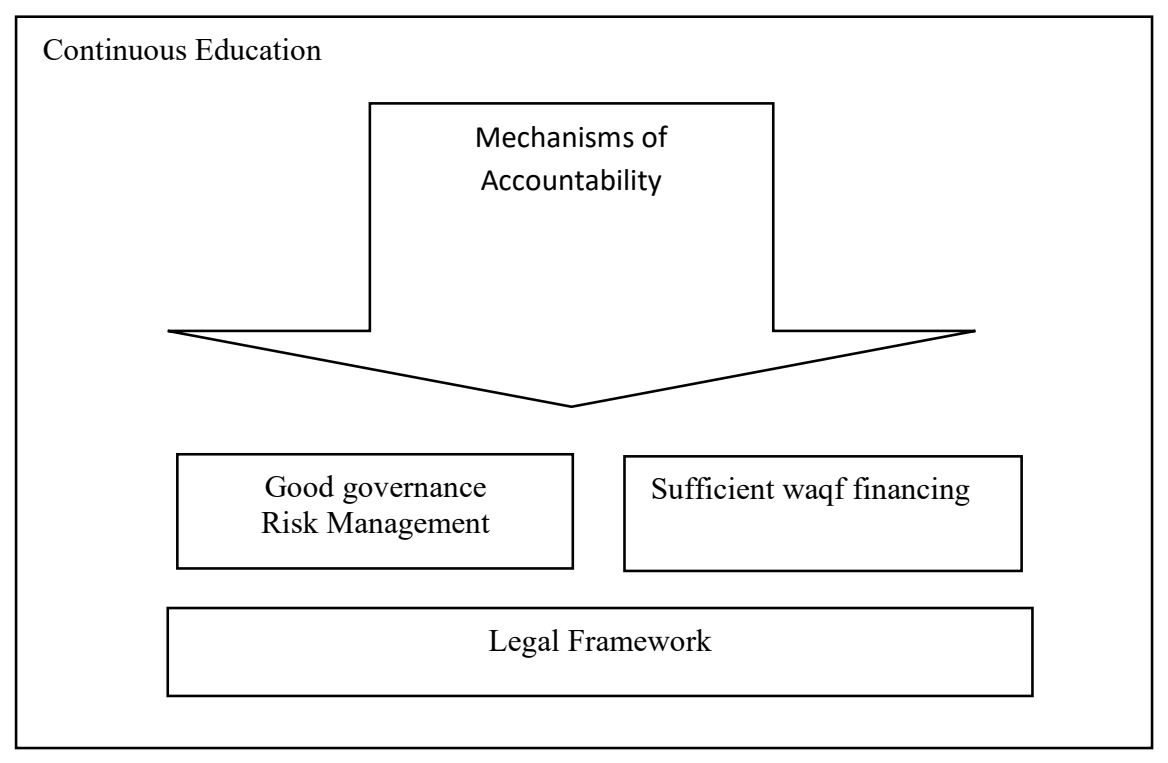

Fig.1. Framework for Effective Waqf Management 
The basis of waqf revitalisation is a clear legal framework. Waqf legislation should be there to protect the assets, waqif, mutawallis and beneficiaries. Waqf provision will enable other stargeties to work i.e. good governance and risk management. Waqf law will also convince the contributors such as donors and financers to contribute to the development of waqf. In order to maintain public accountability on waqf, mechanisms of accountability are needed. Above all, the sustainability of waqf will much rely on public awareness on it. Hence, continuous education to all parties involved in waqf should be conducted.

There are some implications of this study. First, this study is expected to contribute to the regulator in waqf decision making. Second, it is also expected that mutawalli could learn from this study to improve waqf management. Last but not least, for the future study, the upcoming research might assess as to how these factors give impact to an effective waqf administration.

\section{References}

[1] S. K. Rashid, "Necessary Considerations in the Development of Waqf Properties," in Waqf Laws and Management.With Special Reference to Malaysia, 1st ed., S. K. Rashid and A. Hassan, Eds. New Delhi: Genuine Publications \& Media, 2013, pp. 1-28.

[2] H. Yaacob, "Waqf Accounting in Malaysian State Islamic Religios Insitutions: The Case of Federal Territory SIRC," Unpubl. masters Diss. Int. Islam. Univ. Malaysia, Kuala Lumpur, 2006.

[3] H. Ihsan and S. Mohamed Ibrahim, "WAQF accounting and management in Indonesian WAQF institutions: The cases of two WAQF foundations," Humanomics, vol. 27, no. 4, pp. $252-269$, 2011.

[4] S. K. Rashid, "Reason for decline of awqaf and how to bring about their revival," in International conference on waqf and Islamic civilization, 2008, pp. 135-168.

[5] S. AbdulKarim, "Contemporary Waqf Administration and Development in Singapore; Challenges and Prospect," in The Singapore International Waqf Conference, 2007.

[6] M. H. Hanefah, A. Jalil, A. M. Ramli, H. Sabri, N. Nawai, and S. Shahwan, "Financing the Development of Waqf Property: The experience of Malaysia and Singapore," in Waqf Laws and Management.With Special Reference to Malaysia, 1st ed., S. K. Rashid and A. Hassan, Eds. New Delhi: Genuine Publications \& Media, 2013, pp. 299-313.

[7] H. Ihsan, M. Sulaiman, N. M. Alwi, and M. A. Adnan, "A study of accountability practice in Dompet Dhuafa Waqf of Indonesia," J. King Abdulaziz Univ. Islam. Econ., vol. 30, no. 2, pp. 13-32, 2017.

[8] H. Dafterdar, "Towards Effective Legal Regulation and Enabling Environment for Waqf," in Waqf Laws and Management.With Special Reference to Malaysia, 1st ed., S. K. Rashid and A. Hassan, Eds. New Delhi, 2013, pp. 29-46.

[9] V. Braun and V. Clarke, "Using thematic analysis in psychology," Qual. Res. Psychol., vol. 3, pp. 77-101, 2006. 
[10] Bank Indonesia, Wakaf: Pengaturan dan Tata Kelola yang Efektif. Jakarta: Departemen Ekonomi dan Keuangan Syariah Bank Indonesia, 2016.

[11] O. Oseni, "Towards the Effective Legal Regulation of Waqf in Nigeria: Problems and Propects," in Waqf Laws and Management.With Special Reference to Malaysia, 1st ed., S. K. Rashid and A. Hassan, Eds. New Delhi: Genuine Publications \& Media, 2013, pp. 339-354.

[12] A. Trakic, "The Legal and Administrative Analysis of Waqf in Bosnia and Herzegovina," in Waqf Laws and Management.With Special Reference to Malaysia, 1st ed., S. K. Rashid and A. Hassan, Eds. New Delhi: Genuine Publications \& Media, 2013, pp. 315-337.

[13] S. Dorloh, "The Status of Waqf Properties in the Malay-Muslim Majority Areas of Thailand : A Legal survey," in Waqf Laws and Management.With Special Reference to Malaysia, 1st ed., S. K. Rashid and A. Hassan, Eds. New Delhi: Genuine Publications \& Media, 2013, pp. 263-276.

[14] M. F. Karim, "Socio-Legal Perspectives of Awqaf Development in Bangladesh," in Laws and Management.With Special Reference to Malaysia, 1st ed., S. K. Rashid and Hassan.A., Eds. New Delhi: Genuine Publications \& Media, 2013, pp. 277-298.

[15] M. Kahf, "Financing the Development of Waqf Property," in Essential reading in contemporary waqf issues, 1st ed., M. Kahf and Siti-Mashitoh, Eds. Kuala Lumpur: Cert Publications, 2011, pp. 165-202.

[16] H. Ihsan, Eliyanora, and Y. Septriani, "Accountability mechanisms for awqaf institutions: Lessons learnt from the history,” J. King Abdulaziz Univ. Islam. Econ., vol. 29, no. 1, pp. 41$54,2016$.

[17] A. Ayedh, A. Echchabi, and H. Ihsan, "Waqf accountability in the Republic of Yemen: An empiRical analysis,” Qudus Int. J. Islam. Stud., vol. 6, no. 2, pp. 161-180, 2018.

[18] A. Ebrahim, "Accountability in practice: Mechanisms for NGOs," World Dev., vol. 31, no. 5, pp. 813-829, 2003.

[19] S. Gonella, C., Pilling, A. and Zadek, "Making values count: contemporary experience in social and ethical accounting, auditing and reporting," 1998.

[20] F. M. Nasir and H. Ihsan, "Reviving 'waqf' institutions in Indonesia," The Jakarta Post, 2017.

\section{Acknowledgments}

The authors would like to express their gratitute to Politeknik Negeri Padang for the research grant that enabled this study to complete. 